\title{
The impacts of mediating the work environment on the mode choice in work trips
}

https://doi.org/10.1515/eng-2021-0058

Received Sep 27, 2020; accepted Feb 23, 2021

\begin{abstract}
The impacts of work characteristics on travel mode choice behavior has been studied for a long time, focusing on the work type, income, duration, and working time. However, there are no comprehensive studies on the influence of travel behavior. Therefore, this study examines the influence of work environment as a mediator of socio-economic variables, trip characteristics, transportation infrastructure and services, the environment and choice of transportation mode on work trips. The mode of transportation consists of three variables, including public transportation (bus rapid transit and mass rapid transit), private vehicles (cars and motorbikes), and online transportation (online taxis and motorbike taxis online). Multivariate analysis using the partial least squares-structural equation modeling method was used to explain the relationship between variables in the model. According to the results, the mediating impact of work environment is significant on transportation choices only for environmental variables. The mediating mode choice effect is negative for public transportation and complimentary for private vehicles and online transportation. Other variables directly affect mode choice, including the influence of work environment.
\end{abstract}

Keywords: work environment, mediating, work trip, travel behavior, mode choice

\section{Introduction}

To forecast transportation demand, a thorough understanding of travel behavior is necessary. Transportation experts

\footnotetext{
*Corresponding Author: Melchior Bria: Department of Civil
Engineering, Faculty of Engineering, University of Brawijaya, MT.

^Corresponding Author: Melchior Bria: Department of Civil
Engineering, Faculty of Engineering, University of Brawijaya, MT. Haryono Street 167, Malang, East Java, 65145, Indonesia; Email: melchibria@yahoo.co.id

Ludfi Djakfar, Achmad Wicaksono: Department of Civil Engineering, Faculty of Engineering, University of Brawijaya, MT. Haryono Street 167, Malang, East Java, 65145, Indonesia
}

əopen Access. () 2021 M. Bria et al., published by De Gruyter. (cc) BY License and psychologists have broad study experiences on travel behavior, including mode choices during work trips. The general characteristics of work trips include routines on and from trips (commuting), though mode choice is one of the essential stages in transportation planning [1]. In general, mode choice directly affects the transportation policy because it can predict behavior and influencing factors [2]. The decision to travel reflects the alternative modes available, and therefore, it is essential to plan urban transportation systems, especially forecasting travel demand [3, 4]. The pressure due to private vehicle ownership has changed lifestyles and increased outdoor activities, pollution, and congestion [5].

From various mode choice studies, several models have been developed. However, there debates on the right model as choices relates to the inconsistency of people's behavior [6]. Seemingly, various studies reviewed travel demand management to reduce private vehicles' use for satisfaction since 2000 [7]. However, travel model development is mainly used to overcome transportation problems, such as traffic jams, accidents, and pollution [8].

During the last decade, studies related to mode choice on work trips have increased tremendously. Most of them have emphasized on factors influencing workers to use modes and policy solutions in controlling mode choice behavior and realized workers' smart mobility. Frequently studied factors relates to socio-demographic aspects and individual/household characteristics, such as gender, age, number of family members, vehicle ownership, and income [9-15]. Other completed studies focused on travel characteristics, including time, cost and travel distance. Time and cost studies focused on travel time value and its relationship to costs [16]. Additionally, waiting time in modeling travel behavior, leads to satisfaction [17], while travel time is an essential aspect of activity-based travel modeling [18]. Travel distance relates to the existing road network structure and affects time and transportation mode [19].

In the transportation system analysis context, travel occurs through the interaction of transportation systems (modes and infrastructure of transportation) and the activity system [20]. A study on transportation system influence on work trips showed that well-connected road networks 
reduce travel time to work [19]. Infrastructure development, based on intelligent systems, increases public transportation use [21]. Also, good network layout and connectivity increases public transportation use [22]. According to Irfan et al. [23], improving transit services and implementing congestion charges encourage transit use compared to private cars. Additionally, limiting the availability of free parking reduces the use of private cars [24]. According to Huang [25], good accessibility reduces travel time to job location.

Several latent variables that relates to attitudes, behaviors, and lifestyles showed an increased model in explaining modes of choice behavior [26]. Donkor et al. [27] established that attitude as a latent variable and public transportation perceptions affect transportation mode choice for the round trip. However, attitudes towards public transportation mode cannot influence a person's decision to use it in case they own a car [28]. People living in residential areas that use more private vehicles are dissatisfied with their trips than those walking to work [29]. When using the integration choice and latent variable approach, which assumes aspects of security, comfort, safety, public transportation services, and feelings of waiting as latent variables, there is high accuracy in explaining behavior than the traditional logit model [30].

Several studies have examined environmental variables, including land use, as factors influencing mode choice. The built environment and its integration with the road network changed modes' selection in working trips [31, 32]. Land use patterns that produce a certain distance between home and workplace also allow the choice of transportation modes [33].

Some studies analyze aspects related to work because travel is done in the framework of work. Examples of such aspects include the duration of work and start time of work, which affected the choice of transportation mode [34]. Moreover, regulating work duration and start time through management policies (office) leads to flexible work travel [35]. Another challenge to changing car users' behavior to public transportation is the need of incentives stimulation for employees to public transit. However, providing incentives does not make employees walk or use public transportation [24]. Conclusively, factors influencing the mode of choice by people on work trips including the availability of modes, trip, network and work (work time and duration) characters, individual characteristics (socio-demographic, household, ownership vehicle) and attitude or perception related variables [36].

Seemingly, studies related to 'work characteristics' have not comprehensively focused on their effects on mode choice behavior. Efforts to explain office management factors' influence are more related to policy on employee's aspects. Contrastingly, the full work environment has not been fully studied hence has opportunities for policies that can directly lead to realization of smart mobility. It is based on considerations that the work environment is a setting, situation, and condition showing employees' existence. There is also a relationship between employees, employers, and the work environment, including technical, human, and organizational climate [37]. Work environment manifestation occurs through working hours, security and safety, relations with coworkers, esteem needs, and top management [38]. Moreover, the work environment can be viewed based on psychological, physical, and social environment approaches [39, 40]. Some studies show a strong relationship between work environment and employee behavior, which relates to office policy, aspects of the work atmosphere and psychology [41, 42].

This study examines the effect of latent variables work environment (WE), socio-economic (SE), trip characteristics (TC), transportation infrastructure and services (TIS) and the environment (Env) on the choice of transportation modes. Also, the study places work environment as mediation between other variables and transportation modes choice. Consequently, study raised questions are (1) how much influence each of the SE, TC, TIS, Env, and WE variables has against the choice of transportation mode and (2) whether the variables SE, TC, TIS, and Env have an indirect effect on the choice of transportation mode through WE mediation variables. Figure 1 shows the general concept of model development, where SE, TC, TIS, and Env are independent variables and modes of transportation is a dependent. The WE is mediated between the independent and dependent variables. It is an endogenous variable when viewed from a direct relationship with the SE, TC, TIS, and Env. However, it is an exogenous variable when viewed from a direct link with the transportation mode.

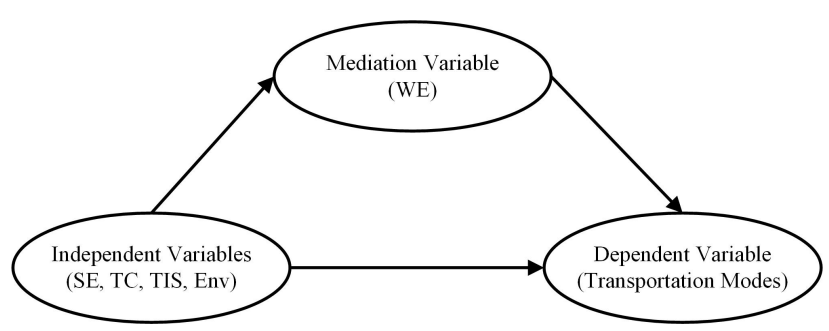

Figure 1: The general concept of model developing

To answer the study questions, the partial least squaresstructural equation modeling (PLS-SEM) was used. SEM is a multivariate analysis technique with the most accurate estimation for simultaneously analyzing multiple regression 
equations [43]. Comparably, PLS is an SEM-based approach on covariance analysis where data are assumed to be abnormally distributed and uses different settings to determine the factor scores [44, 45]. Moreover, PLS-SEM analyzes complex constructs, indicators, and structural paths [46]. This technique has widely been used in transportation studies to evaluate public transit and road safety $[47,48]$, traffic accidents [49], public transportation [50,51], and taxi services [52].

\section{Methods}

\subsection{Area of study and transportation characteristic}

This study was conducted in Jakarta, one of the largest metropolitan cities in Indonesia. Jakarta is divided into six administrative regions covering the North, South, East, West, and one archipelago island (Figure 2) [53], totaling to $662.33 \mathrm{~km}^{2}$ [54]. Currently, the modern operational modes of public transportation in Jakarta include bus rapid transit (BRT) and mass rapid transit (MRT), electric rail trains, and light rail transit (LRT). Also, online modes of transportation positively affect the decisions to travel. This study used Transjakarta BRT, Jakarta MRT, cars, motorbikes, online taxis, and motorbike taxis online to evaluate work trips.

The Transjakarta Company has experienced a significant increase in bus fleets in the last five years [55]. The

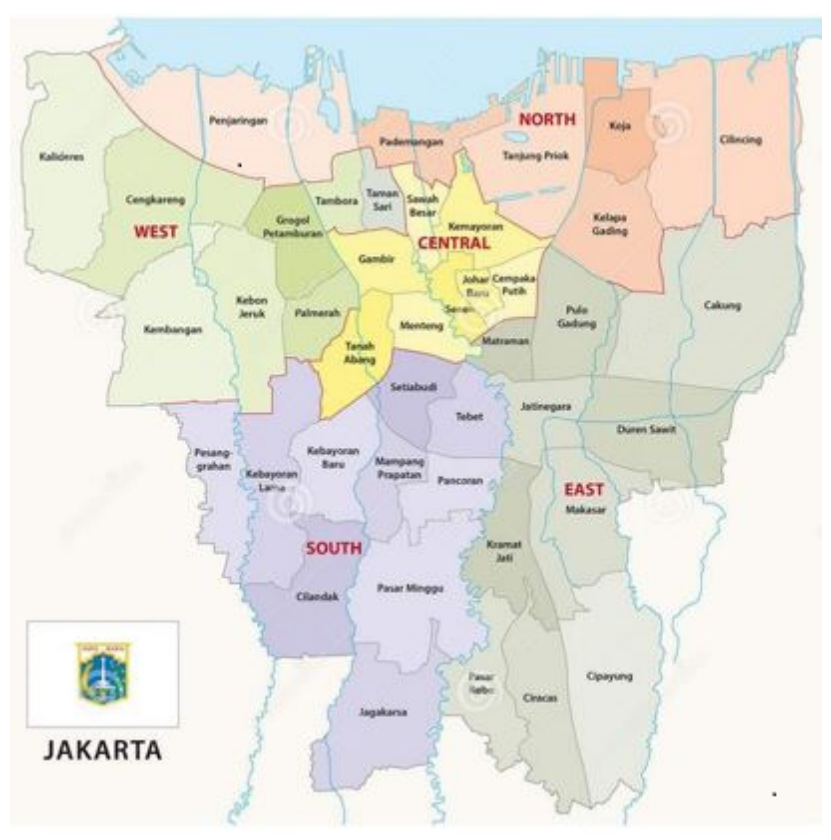

Figure 2: Jakarta map total bus fleet increased from 1325 (in 2014) to 3845 (in 2019), which is in line with Transjakarta bus service routes that grew from 22 in 2014 to 247 in 2019. Consequently, Transjakarta bus passengers have increased by $136 \%$ during the same period [55]. The Jakarta MRT was launched in April 2019, and 79,114 people use its service per day [56]. Online transportation is overgrowing in all cities in Indonesia because of its convenience, web-based ordering ease [57], and availability of discounted programs and vouchers [58]. Comparably, passenger cars and two-wheeled vehicles have increased every year by an average of $6 \%$ for cars and $5 \%$ for motorcycles. The number of cars in 2018 reached 4,133,338, while motorbikes totaled to 16,155,961 units [59].

According to TomTom Traffic data, there was an $8 \%$ decline in Jakarta's traffic congestion from $61 \%$ to $53 \%$ in 2018 [60]. Although the congestion index remained 53\% in 2019, Jakarta's position in the most congested cities worldwide fell from 7 to 10 [60]. This data shows that congestion reduction did not lower its index to below 50\%. Compared to other countries, especially in Europe and America, cities have average congestion indexes below 35\% [60]. This comparison shows that the applied strategies are not optimal in reducing private vehicle dependency. In 2018, 49.5 million trips occurred in Jakarta per day, 23.4 million from the city, while 20.02 million were private vehicle owners from Bogor-Depok-Tangerang-Bekasi (Bodetabek) [61].

\subsection{Model design and hypothesis}

In PLS-SEM, the relationship between variables is shown through a partial regression equation. Each endogenous construct is the dependent variable, and the exogenous construct represents the independent variable, while the indicator measures the construct [62]. Accordingly, there are two elements in the model, specifically the path structure model which is also known as the path structural and outer (measurement) model (reflective and formative indicator model) [63]. Table 1 shows the variable and indicator description.

The structural model is a direct relationship between the variables SE, TC, TIS, Env, and WE concerning the choice of transportation mode and the indirect connection of the variables SE, TC, TIS, Env through WE to transportation choice mode. Modes of transportation were categorized into 3 variables, including public transportation (PT), private vehicles (PV), and online transportation (OT). Consequently, there were 12 patterns of two indirect relationship segments through the WE variable. Also, there were 15 patterns of direct ties to the transportation mode variable with four direct relationships, between SE, TC, TIS, and Env vari- 
Table 1: Variables and indicators in the model

\begin{tabular}{|c|c|c|c|}
\hline No & Variable & Indicator & $\overline{\text { Symbol }}$ \\
\hline \multirow[t]{6}{*}{1} & Socio economic $\left(\xi_{1}\right)$ & Age & $\mathrm{X}_{1}$ \\
\hline & & Number of family members & $x_{2}$ \\
\hline & & Income & $x_{3}$ \\
\hline & & Number of vehicles owned & $\mathrm{X}_{4}$ \\
\hline & & Driving experience & $x_{5}$ \\
\hline & & Work experience & $x_{6}$ \\
\hline \multirow[t]{5}{*}{2} & Trip characteristics $\left(\xi_{2}\right)$ & Travel cost & $x_{7}$ \\
\hline & & Travel time & $x_{8}$ \\
\hline & & Distance & $X_{9}$ \\
\hline & & Travel time to work & $x_{10}$ \\
\hline & & Travel time to home & $\mathrm{x}_{11}$ \\
\hline \multirow[t]{6}{*}{3} & Transportation infrastructure and services $\left(\xi_{3}\right)$ & Availability of transportation infrastructure & $\mathrm{X}_{12}$ \\
\hline & & Availability of parking area & $x_{13}$ \\
\hline & & Connectivity between modes & $\mathrm{x}_{14}$ \\
\hline & & Capacity and services of public transportation & $\mathrm{X}_{15}$ \\
\hline & & Access to public transportation & $x_{16}$ \\
\hline & & Information technology & $\mathrm{X}_{17}$ \\
\hline \multirow[t]{4}{*}{4} & Environment $\left(\xi_{4}\right)$ & The accessibility of workplace location & $\mathrm{X}_{18}$ \\
\hline & & The residential location & $\mathrm{X}_{19}$ \\
\hline & & Road conditions around the residential environment & $x_{20}$ \\
\hline & & Weather and climate conditions & $x_{21}$ \\
\hline \multirow[t]{6}{*}{5} & Work environment $\left(\eta_{1}\right)$ & Work time flexibility & $Y_{1}$ \\
\hline & & Duration & $Y_{2}$ \\
\hline & & Incentives for users of public transportation & $Y_{3}$ \\
\hline & & Sanctions for violating work time discipline & $\mathrm{Y}_{4}$ \\
\hline & & Travel during working hours & $Y_{5}$ \\
\hline & & Job satisfaction & $Y_{6}$ \\
\hline \multirow[t]{2}{*}{6} & Public transportation $\left(\eta_{2}\right)$ & Transjakarta BRT, & $Y_{7}$ \\
\hline & & Jakarta MRT & $Y_{8}$ \\
\hline \multirow[t]{2}{*}{7} & Private vehicle $\left(\eta_{3}\right)$ & Car & $\mathrm{Y}_{9}$ \\
\hline & & Motorcycle & $\mathrm{Y}_{10}$ \\
\hline \multirow[t]{2}{*}{8} & Online transportation $\left(\eta_{4}\right)$ & Online taxi & $\mathrm{Y}_{11}$ \\
\hline & & Motorbike taxis online & $\mathrm{Y}_{12}$ \\
\hline
\end{tabular}

ables and WE. Figure 3 shows the pattern and relationships between variables.

After determining the structural model, the outer model was designed by identifying whether the reflective or formative indicator model formed the variable. Suppose the formative indicator models, changes in construct (variables) are caused by indicator and reflective indicator models if changes in the indicator are caused by construct [64]. The indicators showed a formative relationship in the SE variable because effects in $\mathrm{X}_{1}$ to $\mathrm{X}_{6}$ caused changes in the construct. $\mathrm{X}_{7}$ through $\mathrm{X}_{12}$ were formative indicators because trip characteristics changed based on them. Moreover, $\mathrm{X}_{18}$ through $\mathrm{X}_{21}$ were categorized as formative mod- els because environmental variables caused the indicators that shape them. However, transportation infrastructure and service variables were categorized as reflective because changes in these two factors affected indicators $\mathrm{X}_{13}$ to $\mathrm{X}_{17}$.

The endogenous variables, including public transportation, private vehicles, and online transportation, were categorized as formative model indicators. Changes in indicators $\mathrm{Y}_{1}$ through $\mathrm{Y}_{6}$ affected the work environment, while $\mathrm{Y}_{7}$ to $\mathrm{Y}_{12}$ impacted each variable.

Figure 3 illustrates the hypothesized model that includes a structural model presenting the relationship between variables and the measurement model (the model of the relationship between variables and indicators). Further- 


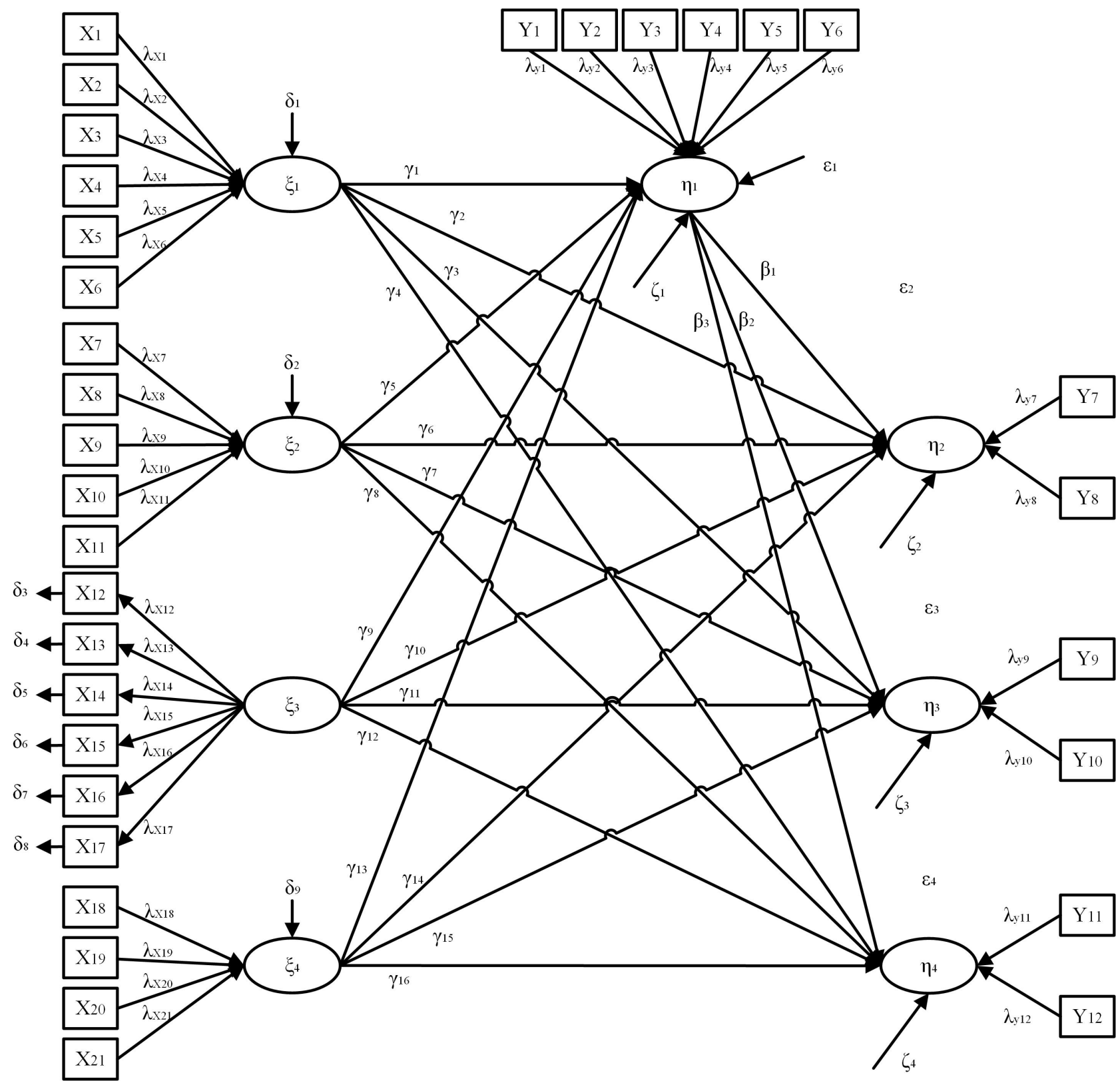

Figure 3: The hypothesized model

more, the model in Figure 3 can be converted into structural equations as follows

a) the equation for the structural model is:

- $\eta_{=1}=\gamma_{1} \xi_{1}+\gamma_{5} \xi_{2}+\gamma_{9} \xi_{3}+\gamma_{13} \xi_{4}+\zeta_{1}$

- $\eta_{2}=\beta_{1} \eta_{1}+\gamma_{2} \xi_{1}+\gamma_{6} \xi_{2}+\gamma_{10} \xi_{3}+\gamma_{14} \xi_{4}+\zeta_{2}$

- $\eta_{3}=\beta_{2} \eta_{1}+\gamma_{3} \xi_{1}+\gamma_{7} \xi_{2}+\gamma_{11} \xi_{3}+\gamma_{15} \xi_{4}+\zeta_{2}$

- $\eta_{4}=\beta_{3} \eta_{1}+\gamma_{4} \xi_{1}+\gamma_{8} \xi_{2}+\gamma_{12} \xi_{3}+\gamma_{16} \xi_{4}+\zeta_{2}$ b) the equation for the outer model is:

1) for exogenous variables $\xi_{1}, \xi_{2}$ dan $\xi_{4}$ (formative indicator model)

$$
\begin{aligned}
-\xi_{1} & =\lambda_{x 1} X_{1}+\lambda_{x 2} X_{2}+\lambda_{x 3} X_{3}+\lambda_{x 4} X_{4} \\
& +\lambda_{x 5} X_{5}+\lambda_{x 6} X_{6}+\delta_{1} \\
-\xi_{2} & =\lambda_{x 7} X_{7}+\lambda_{x 8} X_{8}+\lambda_{x 9} X_{9}+\lambda_{x 10} X_{10} \\
& +\lambda_{x 11} X_{11}+\delta_{2} \\
-\xi_{4} & =\lambda_{x 18} X_{18}+\lambda_{x 19} X_{19}+\lambda_{x 20} X_{20} \\
& +\lambda_{x 21} X_{21}+\delta_{9}
\end{aligned}
$$


2) for exogenous variables $\xi_{3}$ (reflective indicator model)

- $X_{12}=\lambda_{x 12} \xi_{3}+\delta_{3}$

- $X_{13}=\lambda_{x 13} \xi_{3}+\delta_{4}$

- $X_{14}=\lambda_{x 14} \xi_{3}+\delta_{5}$

- $X_{15}=\lambda_{x 15} \xi_{3}+\delta_{6}$

- $X_{16}=\lambda_{x 16} \xi_{3}+\delta_{7}$

- $X_{17}=\lambda_{x 17} \xi_{3}+\delta_{8}$

3) for endogenous variables (formative indicator model)

- $\eta_{1}=\lambda_{Y 1} y_{1}+\lambda_{Y 2} y_{2}+\lambda_{Y 3} y_{3}+\lambda_{Y 4} y_{4}$

$+\lambda_{Y 5} y_{5}+\lambda_{Y 6} y_{6}+\epsilon_{1}$

- $\eta_{2}=\lambda_{Y 7} y_{7}+\lambda_{Y 8} y_{8}+\epsilon_{2}$

- $\eta_{3}=\lambda_{Y 9} y_{9}+\lambda_{Y 10} y_{10}+\epsilon_{3}$

- $\eta_{4}=\lambda_{Y 11} y_{11}+\lambda_{Y 12} y_{12}+\epsilon_{4}$

Note

$\xi$ : exogenous latent variables

$\eta$ : endogenous latent variables

$\gamma$ : coefficient effect of exogenous variables on endogenous variables

$\beta$ : coefficient of influence of endogenous variables on endogenous variables

$\lambda_{x}$ : the loading factor of the exogenous variables

$\lambda_{y}$ : the loading factor of the endogenous variables

$\zeta$ : model error

$\delta$ : measurement error in exogenous latent variables

$\varepsilon$ : measurement error in endogenous latent variables

\subsection{Evaluation model parameters}

Evaluation was conducted using the outer and structural model where by the outer model determined whether reflective and formative indicators meet validity and reliability requirements. Contrastingly, the structural model determines how strongly the situation is explained and the relationship between variables. Table 2 shows the parameters used to evaluate the structural and outer models $[46,64,65]$.

$R^{2}$ and $Q^{2}$ parameters measured the influence of SE, TC, TIS, Env, and WE variables on transportation mode choice (to answer the first research question). Moreover, path coefficient relevance evaluated the mediation effects of direct and indirect relationships between variables (to answer the second research question).

\subsection{Data collection and sample}

Data was collected using a survey questionnaire designed to measure variables indicators, as shown in Table 1. Nominal scales analyzed TC variables, while the SE variables used ratio data. Furthermore, questions measuring TIS, Env, WE, PT, PV, and OT variables used a scale of 1-10, where one and ten presented strongly disagree to strongly agree respectively.

Formal sector workers with monthly income jobs in legal businesses, organizations, and government agencies were used as the study sample. Respondents were Jakarta residents who travelled from home to work every day following their respective jobs' characteristics.

Data was sampled through a simple random technique, a method widely used for mode choice surveys [66]. Questionnaires were distributed to activity centers such as private offices, government offices, business, and trade centers. The number of respondents required in the PLS-SEM analysis using the survey method was determined based on the formula [67] below:

$$
N=\left(\frac{Z_{C L}+Z_{F P}}{|\hat{\beta o}|}\right)^{2}
$$

Table 2: Model evaluation criteria

\begin{tabular}{cc}
\hline Model & Evaluation parameters \\
\hline $\begin{array}{c}\text { Reflective indicator model } \\
\text { Formative indicator model } \\
\text { Structural model }\end{array}$ & Internal reliability, indicator reliability, convergent validity, discriminant validity. \\
& Collinearity (variance inflation factor (VIF)) dan indicator weight \\
& Collinearity (VIFs), predictive relevance $\left(\mathrm{R}^{2}\right.$ dan $\left.\mathrm{Q}^{2}\right)$, significance and relevance of \\
path coefficients.
\end{tabular}


$Z_{C L}$ : value based on the level of trust

$Z_{F P}$ : the value of the percentage of errors that might occur $|\hat{\beta o}|$ : the absolute value of estimation, determined 0.0215

The $Z_{C L}$ and $Z_{F P}$ values were 1.6449 and 1.2816 while maintaining a 5\% error with a minimum number of 286 respondents [67]. In this study, 331 of the 350 survey questionnaires followed the appropriate criteria.

\section{Results}

\subsection{Outer model evaluation}

The outer model test evaluated the validity and reliability requirements of reflective indicators because it has a reflective model. Contrastingly, formative indicators were tested with a different approach because the outer model cannot evaluate ordinary formative validity and reliability $[51,65]$.

The evaluation of reflective models measured convergent and discriminant validity and composite and internal reliability. Measurement of convergent validity refers to loadings values $>0.7[46,64]$ and p-values $<0.05[65]$. However, there are also more conservative opinions by still accepting loadings $>0.5$ [68]. Moreover, other parameters were used to assess convergent validity based on the average variance extracted (AVE) value $>0.5$ [46]. Therefore, some indicators in the reflective model (Table 3) must be excluded from the model if it refers to a value of loadings $>0.7$. However, if it refers to a value of loadings $>0.5$, all indicators remain included in the model. However, judging from the AVE value of 0.458 (Table 5), the TIS variable does not meet the convergent validity requirements if using all the model indicators.

Several studies have used Fornell-Larcker criteria to latent variables discriminant validity [69], while some apply cross-loadings methods [70, 71]. The cross-loadings value in Table 3 shows that indicator $\mathrm{X}_{13}$ has a lower loading value on its variable (TIS) than on PV. Consequently, the $\mathrm{X}_{13}$ indicator had the lowest loadings (0.511) and was removed because it did not meet the discriminant validity requirements. Table 4 shows that each latent variable had a greater AVE square root than its correlation value. Moreover, the TIS reflective variable AVE square root of 0.677 is

Table 3: Loadings and cross loadings values for the test of the validity of reflective indicators

\begin{tabular}{cccccccccc}
\hline Reflective & \multicolumn{7}{c}{ Variable } \\
\cline { 2 - 10 } indicator & SE & TC & TIS & Env & WE & PT & PV & OT & p-value \\
\hline $\mathrm{X}_{12}$ & -0.033 & -0.005 & $\mathbf{0 . 7 0 4}$ & -0.134 & -0.008 & -0.053 & 0.108 & -0.011 & $<0.001$ \\
$\mathrm{X}_{13}$ & -0.15 & -0.089 & $\mathbf{0 . 5 1 1}$ & 0.192 & 0.164 & 0.157 & 0.535 & -0.059 & $<0.001$ \\
$\mathrm{X}_{14}$ & 0.02 & 0.115 & $\mathbf{0 . 8 0 8}$ & -0.094 & -0.046 & -0.149 & -0.202 & -0.013 & $<0.001$ \\
$\mathrm{X}_{15}$ & 0.047 & 0.033 & $\mathbf{0 . 7 5 7}$ & -0.038 & 0.05 & 0.094 & -0.013 & 0.089 & $<0.001$ \\
$\mathrm{X}_{16}$ & -0.023 & 0.076 & $\mathbf{0 . 6 8 7}$ & 0.059 & 0.078 & 0.152 & -0.13 & -0.242 & $<0.001$ \\
$\mathrm{X}_{17}$ & 0.117 & -0.224 & $\mathbf{0 . 5 4 2}$ & 0.112 & -0.246 & -0.181 & -0.16 & 0.273 & $<0.001$ \\
\hline
\end{tabular}

Table 4: Correlations among latent variables with square roots of AVEs

\begin{tabular}{ccccccccc}
\hline Correlations & SE & TC & TIS & Env & WE & PT & PV & OT \\
\hline SE & $\mathbf{0 . 7 6 4}$ & 0.369 & 0.136 & 0.424 & 0.411 & -0.055 & 0.343 & -0.022 \\
TC & 0.369 & $\mathbf{0 . 6 1 1}$ & 0.036 & 0.228 & 0.173 & -0.007 & 0.122 & -0.192 \\
TIS & 0.136 & 0.036 & $\mathbf{0 . 6 7 7}$ & 0.464 & 0.243 & 0.518 & -0.058 & 0.43 \\
E & 0.424 & 0.228 & 0.464 & $\mathbf{0 . 6 9 2}$ & 0.56 & -0.077 & 0.367 & 0.306 \\
WE & 0.411 & 0.173 & 0.243 & 0.56 & $\mathbf{0 . 5 3 9}$ & -0.2 & 0.442 & 0.213 \\
PT & -0.055 & -0.007 & 0.518 & -0.077 & -0.2 & $\mathbf{0 . 6 7 9}$ & -0.513 & 0.126 \\
PV & 0.343 & 0.122 & -0.058 & 0.367 & 0.442 & -0.513 & $\mathbf{0 . 6 1 7}$ & 0.005 \\
OT & -0.022 & -0.192 & 0.43 & 0.306 & 0.213 & 0.126 & 0.005 & $\mathbf{0 . 8 7 4}$ \\
\hline
\end{tabular}

Table 5: Latent variable coefficients for the reflective variable

\begin{tabular}{cccc}
\hline Variable & AVE & Composite reliability & Cronbach's alpha \\
\hline Transportation infrastructure and services & 0.458 & 0.832 & 0.755 \\
\hline
\end{tabular}


greater than the its correlation value with SE (0.136), TC (0.036), Env (0.464), WE (0.243), PT (0.518), PV (-0.058) and OT (0.43). Consequently, the TIS variable met the discriminant validity requirement. The same criterion can be applied in formative latent variability models [65] to ensure all variables in the model meet discriminant validity requirements.

The composite reliability $>0.7$ and Cronbach's alpha > 0.7 parameters were used to evaluate the reflective model reliability $[46,63,65,68]$. Table 5 shows that the composite reliability and Cronbach's alpha values were $>0.7$, hence the reflective indicator model met the reliability criteria.

The formative model was evaluated based on the significant value of $p$-value $(<0.05)$ and VIF to ensure formative latent variables' suitability. The same concept applies to multiple linear regression analyses, which, in many aspects, is parallel to the PLS-SEM [65]. VIF examination confirmed the presence or absence of multicollinearity in the model. The ideal VIF value is less than 3.3, but more conservative provisions allow VIF $<5$ up to $<10[65,72]$. This study used the VIF limit $<5$ as shown in Table 6 whereby the $p$-value of indicator $\mathrm{X}_{1}$ is less than 0.05 and its VIF value $>5$ hence excluded from the model. Similarly, the indicator $\mathrm{X}_{11}$ was $\mathrm{p}$-value $>0.05$, hence it was excluded from the model even with VIF $<5$. The indicator variables excluded from the model are age $\left(\mathrm{X}_{1}\right)$, travel time to home $\left(\mathrm{X}_{11}\right)$, and availability of parking space $\left(\mathrm{X}_{13}\right)$. From the second analysis, all reflective indicators' loadings were $>0.5$, AVE from the reflective model was $>0.5$ (0.513). It also had a composite reliability coefficient of 0.838 and Cronbach's alpha coefficient of 0.757 . The cross-loadings and AVE roots in the first analysis showed no significant changes hence the reflective model in the second analysis met the validity and reliability requirements. Furthermore, all formative indicators of SE, TC, Env, WE, PT, PV, and OT variables were significant < 0.05 with VIF $<5$ and proceeded to the structural model test.

Table 6: $p$-value and VIF of formative indicator

\begin{tabular}{|c|c|c|c|c|}
\hline Variable & Indicator & $p$-value & VIF & $\overline{\text { Result }}$ \\
\hline \multirow[t]{6}{*}{ Socio-economic } & $\mathrm{X}_{1}$ & $<0.001$ & 5.677 & Rejected \\
\hline & $x_{2}$ & $<0.001$ & 1.376 & Accepted \\
\hline & $x_{3}$ & $<0.001$ & 2.709 & Accepted \\
\hline & $X_{4}$ & $<0.001$ & 1.997 & Accepted \\
\hline & $X_{5}$ & $<0.001$ & 2.085 & Accepted \\
\hline & $x_{6}$ & $<0.001$ & 4.707 & Accepted \\
\hline \multirow[t]{5}{*}{ Trip characteristics } & $\mathrm{X}_{7}$ & $<0.001$ & 1.115 & Accepted \\
\hline & $\mathrm{X}_{8}$ & $<0.001$ & 1.993 & Accepted \\
\hline & $X_{9}$ & $<0.001$ & 1.901 & Accepted \\
\hline & $\mathrm{X}_{10}$ & 0.011 & 1.357 & Accepted \\
\hline & $\mathrm{X}_{11}$ & 0.158 & 1.354 & Rejected \\
\hline \multirow[t]{4}{*}{ Environment } & $\mathrm{X}_{18}$ & $<0.001$ & 1.168 & Accepted \\
\hline & $\mathrm{X}_{19}$ & $<0.001$ & 1.18 & Accepted \\
\hline & $x_{20}$ & $<0.001$ & 1.444 & Accepted \\
\hline & $x_{21}$ & $<0.001$ & 1.27 & Accepted \\
\hline \multirow[t]{6}{*}{ Work environment } & $Y_{1}$ & $<0.001$ & 1.059 & Accepted \\
\hline & $\mathrm{Y}_{2}$ & $<0.001$ & 1.066 & Accepted \\
\hline & $Y_{3}$ & $<0.001$ & 1.209 & Accepted \\
\hline & $Y_{4}$ & $<0.001$ & 1.1 & Accepted \\
\hline & $Y_{5}$ & $<0.001$ & 1.159 & Accepted \\
\hline & $\mathrm{Y}_{6}$ & $<0.001$ & 1.199 & Accepted \\
\hline \multirow[t]{2}{*}{ Public transportation } & $\mathrm{Y}_{7}$ & $<0.001$ & 1.006 & Accepted \\
\hline & $Y_{8}$ & $<0.001$ & 1.006 & Accepted \\
\hline \multirow[t]{2}{*}{ Private vehicle } & $Y_{9}$ & $<0.001$ & 1.061 & Accepted \\
\hline & $Y_{10}$ & $<0.001$ & 1.061 & Accepted \\
\hline \multirow[t]{2}{*}{ Online transportation } & $\mathrm{Y}_{11}$ & $<0.001$ & 1.384 & Accepted \\
\hline & $Y_{12}$ & $<0.001$ & 1.384 & Accepted \\
\hline
\end{tabular}




\subsection{Structural model evaluation}

The structural model showed the influence of one variable on another. Secondly, coefficients $\mathrm{R}^{2}$ and $\mathrm{Q}^{2}$ were used to explain the strength of exogenous variables and each variable's predictive validity. $R^{2}$ is low if 0.25 , moderate if 0.5 , substantial if 0.75 and $Q^{2}>0$ is small, $>0.25$ is middle, $>0.5$ is high [46], hence the coefficient only applied to endogenous variables. However, a prior examination of collinearity was needed to ensure an unbiased regression analysis [46]. VIFs values of all latent variables were seen to meet the requirements $<5$ [72], which showed no collinearity symptoms in the model (Table 7 ).
Table 7 also shows an $\mathrm{R}^{2}$ coefficient of 0.236 , WE variable of 0.391 for the PT variable, 0.347 for the PT variable, and 0.341 for the OT variable. This shows the effect of SE, TC, TIS, and Env on the WE variable is relatively weak $(<0.25)$ or was only $23.6 \%$ and other variables outside the model influenced the rest. Contrastingly, the effects of SE, TC, TIS, Env, and WE on transportation modes $>0.25$, which means the effect did not reach moderate levels. The $Q^{2}$ coefficient for endogenous variables WE, PT, PT, and OT was $>0.25$ hence classified in the medium category.

The evaluation of direct and indirect variables relations in the model based on p-value $<0.05[46,63,65]$ is Figure 4 and Table 8. From the results, TIS, Env, and WE variables had a significant effect on all modes of transporta-

Table 7: Latent variable coefficients for evaluation of structural models

\begin{tabular}{ccccccccc}
\hline \multirow{2}{*}{ Coefficients } & \multicolumn{7}{c}{ Variable } \\
\cline { 2 - 9 } & SE & TC & TIS & Env & WE & PT & PV & OT \\
\hline VIFs & 1.459 & 1.223 & 2.253 & 2.048 & 1.696 & 2.166 & 1.781 & 1.372 \\
$\mathrm{R}^{2}$ & & & & & 0.236 & 0.391 & 0.347 & 0.341 \\
$\mathrm{Q}^{2}$ & & & & & 0.413 & 0.433 & 0.367 & 0.332 \\
\hline
\end{tabular}

Table 8: Output test the relationship between variables in the model

\begin{tabular}{lcccc}
\hline Hypothesis relations between variables & $\begin{array}{c}\text { Path } \\
\text { coefficients }\end{array}$ & $\begin{array}{c}\text { p- } \\
\text { values }\end{array}$ & $\begin{array}{c}\text { Indirect } \\
\text { effects }\end{array}$ & $\begin{array}{c}\text { p-values of } \\
\text { indirect } \\
\text { effects }\end{array}$ \\
\hline Socio-economic - Work environment & 0.175 & $<0.001$ & - & - \\
Socio-economic - Public transportation & 0.061 & 0.133 & -0.029 & 0.230 \\
Socio-economic - Private vehicle & 0.180 & 0.001 & 0.047 & 0.111 \\
Socio-economic - Online transportation & -0.096 & 0.038 & 0.03 & 0.222 \\
Trip characteristics - Work environment & -0.051 & 0.177 & - & - \\
Trip characteristics - Public transportation & 0.058 & 0.143 & 0.008 & 0.416 \\
Trip characteristics - Private vehicle & -0.040 & 0.231 & -0.014 & 0.362 \\
Trip characteristics - Online transportation & -0.129 & 0.009 & -0.009 & 0.413 \\
Transportation infrastructure and services - Work environ- & -0.195 & $<0.001$ & - & - \\
ment & & & & \\
Transportation infrastructure and services - Public transporta- & 0.553 & $<0.001$ & 0.032 & 0.206 \\
tion & & & & \\
Transportation infrastructure and services - Private vehicle & -0.280 & $<0.001$ & -0.053 & 0.087 \\
Transportation infrastructure and services - Online trans- & 0.200 & $<0.001$ & -0.033 & 0.197 \\
portation & & & & - \\
Environment - Work environment & 0.428 & $<0.001$ & - & - \\
Environment - Public transportation & -0.133 & 0.007 & -0.07 & 0.035 \\
Environment - Private vehicle & 0.127 & 0.009 & 0.115 & 0.001 \\
Environment - Online transportation & 0.322 & $<0.001$ & 0.072 & 0.030 \\
Work environment - Public transportation & -0.163 & 0.001 & - & - \\
Work Environment - Private vehicle & 0.270 & $<0.001$ & - & - \\
Work Environment - Online transportation & 0.169 & $<0.001$ & - & - \\
\hline
\end{tabular}




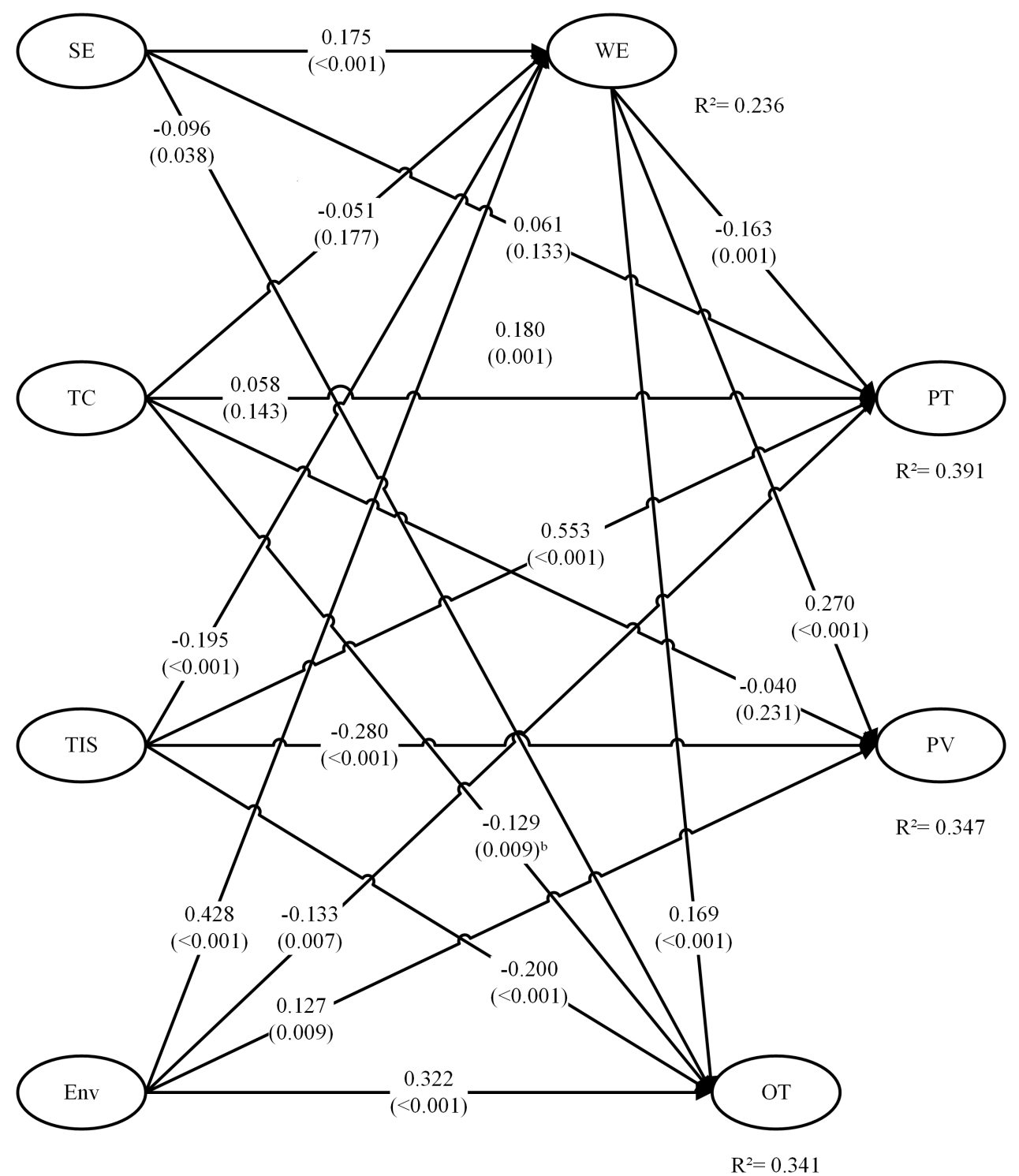

Figure 4: Result of the structural model analysis

tion choices. Contrastingly, the SE variable only affected the choice of PV and OT modes, while TC had a significant effect on OT. A significant indirect effect only occurred on the Env variable, hence it had an indirect impact on the choice of modes of public transportation, private vehicles, and online transportation through WE mediation variables.

\section{Discussion}

The mediating effect of the WE variable and the influence of other dependent variables on the choice of transportation mode is known. Results showed that the mediating effect of WE variables on transportation mode choice was signifi- cant for the Env variable. The indirect relationship between the Env variable with PT was negative, with a path coefficient of -0.07 and a significant level $<0.05$ (Table 8). Consequently, growing environmental conditions change, and the working climate reduces public transportation modes. The indirect effect of Env on PV mode was significant with a path coefficient of 0.115 , which is more than its effect on OT mode (0.072). These results showed that the increasing use of PV and OT modes is associated with increased environmental conditions through the work environment. Also, the Env variable positively affects PV and OT mode choice but is negative for PT mode.

As in previous studies, the results proved that the integration of road networks in settlements with the built 
environment substantially influenced mode choices [32]. Also, residence and work locations have an impact on travel mode choices [73]. Workplace accessibility, residential locations, environmental road conditions, and increased climate change reduced public transportation use. Therefore, an integrated area arrangement with public transportation is essential and follows private vehicles' use restrictions.

The WE variable's direct influence had a significant effect on all choices of transportation modes. However, WE on PT's choice impact is significant with a negative path coefficient is -0.163 , meaning that increasing changes in the WE variable effect decreased PT's use. Moreover, an increase in the flexibility indicator of working hours does not necessarily increase public transportation use. Contrastingly, previous studies show that some working hours settings can increase flexibility and encourage public transportation [35]. The finding was in line with several other studies stating that increasing work duration impacts the reduced use of PT mode [26, 74]. Giving incentives to public transportation users decreases the use of that mode of transportation [24]. Increased work time violations, travel time during work hours, and job satisfaction decreased PT mode choice, hence policies can be used to control the use of private vehicles on work trips. The positive effect of WE were PV (0.270) and OT (0.169) modes, while opposite behavior increased flexibility of working hours, duration and provision of incentives, sanctions for disciplinary violations, travel during working hours, and job satisfaction.

Apart from work environment, TIS variable also affected all modes of transportation choices significantly. Other indicators, including transportation infrastructure, mode connectivity, public transportation capacity and service, access to public transportation, and information technology in transportation, significantly affected transportation choice. Therefore, the provision of good urban transportation infrastructure and accessibility provides ease in traveling, hence impacting the choice of mode of travel [19, 21, 22, 75]. In the PV mode, the path coefficient was negative by $(-0.280)$, which increased the TIS and reduced the use of PV. There was a strong relationship between increased transportation infrastructure and the PT mode use. PT path coefficient was 0.553 , providing transportation infrastructure and improving services will continuously reduce the dependence on private vehicles.

The SE variable only affected the PV and OT modes compared to the TIS and Env variables, which significantly impacted all modes. Moreover, the SE variable is positively impacted $P V$ with a path coefficient of 0.180 and was negative to OT mode $(-0.096)$. These impacts show that increased family members, income, vehicle ownership, driving experience, and work experience increased PV use. To control this effect, ownership control policies, for example, limiting carbon dioxide emissions [76], production years vehicle sanctions, and other alternatives can be implemented.

Finally, the TC variable affected online transportation mode with a path coefficient of -0.129 such that increased costs, time, and distance and travel time to work decreased the use of OT. However, the OT is user simplicity [57], and service improvement [77] will sustain the online transportation network.

\section{Conclusions}

This study examined the indirect effect of independent variables on socio-economic, trip characteristics, transportation infrastructure and services, and the work environment as mediating variables. Results showed that the work environment variable's mediating effect occurs on environmental variables only, while other variables directly influence the mode choice. Moreover, the most significant influence was on private vehicle mode (11.5\%), hence the need for good environmental and work policies to reduce its use.

Transportation infrastructure and services had the highest direct effect on mode choice by contributing 55.3\% to public transportation. Furthermore, the work environment had the largest positive direct impact on private vehicles by $27 \%$. In online transportation, the most significant positive influence from environmental variables was $32.2 \%$. Contrastingly, public transportation was negatively impacted by the work environment by $16.3 \%$. The private vehicle mode was negatively impacted by transportation infrastructure and services by $28 \%$. The most significant negative effect on online transportation was from the trip characteristics at $12.9 \%$.

Providing infrastructure and transportation services is not sufficient to encourage public transportation use on routine work trips. The government should implement infrastructure development with regional managements that increases mobility and high accessibility for public transportation. Moreover, transportation policies should be integrated with workplace policies. Some general transportation policies include efforts to reduce travel (avoid), using public transit (shift) and technological innovations related to environmentally friendly vehicles (improve). Therefore, integrating workplace policy with an avoid-shift-improve strategy is an excellent way to encourage workers to use public transportation.

This study enriched previous literature through the inclusion of work environment factors as variables that influence work trips. Comparably, previous studies examined 
work factors in terms of work duration and efforts to provide public transportation users incentives without analysing its effects. However, work-related aspects are comprehensive and cannot be explained by the duration and working time. The study grouped these variables into the work environment by adding indicators of sanctions for violations of work time discipline, travel during working hours, and job satisfaction, and the results showed significant effects. Some of the variable indicators to use as additional study materials include 1) Travel during working hours, can be used as study material to answer how these trips are carried out. 2) Time to travel during working hours can analyse congestion effects and levels in urban areas. Furthermore, further research can add other variables such as the nature of work and the Covid-19 effects on travel choices. For future studies, this model will be developed with a consumer psychology approach by assuming that employees are consumers to describe the mode choice behavior.

Acknowledgement: The authors express gratitude to the Ministry of Research and Technology / National Research and Innovation Agency of the Republic Indonesia-Deputy for Research and Development Strengthening for the funding provided to complete this research.

\section{References}

[1] Minal, Sekhar CR. Mode choice analysis: the data, the models and future ahead. Int J Traffic Transp Eng [Internet]. 2014 [cited 2020 July 5];4(3):269-85. Available from: http://dx.doi.org/10. 7708/ijtte.2014.4(3).03.

[2] Ortuzar JD, Willumsen LG. Modeling Transport. 4th ed. New York: Wiley \& Sons; 2011.

[3] McNally MG. The four step model. In: Hensher DA, Button KJ, editors. Handbook of transport modelling. 1st ed. Wagon Lane, Binglay: Emerald; 2008. p. 35-53.

[4] Jayasinghe A, Sano K, Rattanaporn K. Application for developing countries: Estimating trip attraction in urban zones based on centrality. J Traffic Transp Eng (English Ed) [Internet]. 2017 Sept [cited 2020 July 5];4(5):464-76. Available from: https://doi.org/ 10.1016/j.jtte.2017.05.011.

[5] Yang J, Kato H, Ando R, Nishihori Y. Analyzing household vehicle ownership in the Japanese local city: case study in Toyota city. J Adv Transp [Internet]. 2020 Mar [cited 2020 July 5];2020:1-11. Available from: https://doi.org/10.1155/2020/7264860.

[6] Garling T. Behavioural assumptions overlooked in travel choice modelling. In: Ortuzar JD, Hensher D, Diaz SJ, editors. Travel behaviour research: Updating the state of play. Netherlands: Elsevier Science Ltd; 1998. p. 3-18.

[7] Garling T. Travel behavior and psychology: life time achievement 1982-2018. In: Goulias KG, Davis AW, editors. Mapping the travel behavior genome. Netherlands: Elsevier Inc.; 2020. p. 47-61.
[8] Goulias KG, Davis AW, McBride EC. Introduction and the genome of travel behavior. In: Goulias KG, Davis AW, editors. Mapping the travel behavior genome. Netherlands: Elsevier Inc.; 2020. p. 1-14.

[9] Almasri E, Alraee S. Factors affecting mode choice of work trips in developing cities-Gaza as a case study. J Transp Technol [Internet]. 2013 Oct [cited 2020 July 12];3(4):247-59. Available from: https://doi.org/10.4236/jtts.2013.34026.

[10] Tushara T, Rajalakshmi P, Koshy BI. Mode choice modelling for work trips in Calicut City. Int J Innov Technol Explor Eng [Internet]. 2013 Aug [cited 2020 July 12];3(3):106-13. Available from: https: //www.ijitee.org/download/volume-3-issue-3/.

[11] Ashrafi SR, Neumann HM. Determinants of transport mode choice in the Austrian Province of Vorarlberg. In: Schrenk M, Popovich VV, Zeile P, Elisei P BC, editors. Panta Rhei - A World in Constant Motion [Internet]. 2017 Sep 12-14 [cited 2020 July 12]. Vienna, Austria: Corp; p. 121-30. Available from: https://programm.corp. at/cdrom2017/papers2017/CORP2017_52.pdf.

[12] Chanda R, Sen S, Roy KS. Mode choice modelling of work trips: A case study of Kolkata. In: Proc of the Fourth International Conference on Advances in Civil, Structural and Enviromental Engineering [Internet]. 2016 Dec 15-16 [cited 2020 July 12]. Rome, Italy: Institute of Research Engineers and Doctors; p. 41-5. Available from: https://www.seekdl.org/conferences/paper/details/ 8452.

[13] Athira IC, Muneera CP, Krishnamurthy K, Anjaneyulu MVLR. Estimation of value of travel time for work trips. Transportation Research Procedia [Internet]. 2016 [cited 2020 July 12];17:11623. Available from: https://doi.org/10.1016/j.trpro.2016.11.067.

[14] Bjørkelund OA, Degerud H, Bere E. Socio-demographic, personal, environmental and behavioral correlates of different modes of transportation to work among Norwegian parents. Arch Public Heal [Internet]. 2016 Oct [cited 2020 July 26];74(43):1-9. Available from: http://dx.doi.org/10.1186/s13690-016-0155-7.

[15] Mayo FL, Taboada EB. Ranking factors affecting public transport mode choice of commuters in an urban city of a developing country using analytic hierarchy process: The case of Metro Cebu, Philippines. Transp Res Interdiscip Perspect [Internet]. 2020 Mar [cited 2020 July 12];4:1-12. Available from: https://doi.org/10.1016/j.trip.2019.100078.

[16] Dubernet I, Dubernet T, Axhausen KW. Comparing values of travel time obtained from workplace and short-term decisions. Travel Behav Soc [Internet]. 2020 July [cited 2020 July 12];20:83-90. Available from: https://doi.org/10.1016/j.tbs.2020.02.002.

[17] Han Y, Li W, Wei S, Zhang T. Research on passenger's travel mode choice behavior waiting at bus station based on SEMlogit integration model. Sustain [Internet]. 2018 Jun [cited 2020 July 12];10(6):1-23. Available from: https://doi.org/10.3390/ su10061996.

[18] Zhong M, Shan R, Du D, Lu C. A comparative analysis of traditional four-step and activity-based travel demand modeling: a case study of Tampa, Florida. Transp Plan Technol. 2015 Jun;38(5):51733.

[19] Parthasarathi P, Levinson D. Network structure and the journey to work: An intra-metropolitan analysis. Transp Res Part A Policy Pract. 2018 Dec;118:292-304.

[20] Mathew TV. Introduction to transportation system analysis. [lecture notes on Internet]. IIT Bombay; 2019 [cited 2020 July 13]. p. 1-10 Available from: https://www.civil.iitb.ac.in/tvm/nptel/101_ TptnIntro/web/web.html. 
[21] Chakrabarti S. How can public transit get people out of their cars? An analysis of transit mode choice for commute trips in Los Angeles. Transp Policy. 2017 Feb;54:80-9.

[22] Papaioannou D, Martinez LM. The role of accessibility and connectivity in mode choice. A structural equation modeling approach. Transportation Research Procedia [Internet]. 2015 [cited 2020 July 13];17:831-9. Available from: http://dx.doi.org/10. 1016/j.trpro.2015.09.036.

[23] Irfan M, Khurshid AN, Khurshid MB, Ali Y, Khattak A. Policy implications of work-trip mode choice using econometric modeling. J Transp Eng Part A Syst. 2018;144(8):1-10.

[24] Ferrer HB, Cooper A, Audrey S. Associations of mode of travel to work with physical activity, and individual, interpersonal, organisational, and environmental characteristics. J Transp Heal [Internet]. 2018 Jun [cited 2020 July 13];9:45-55. Available from: https://doi.org/10.1016/j.jth.2018.01.009.

[25] Huang R. Simulating individual work trips for transit-facilitated accessibility study. Environ Plan B Urban Anal City Sci [Internet]. 2017 Apr [cited 2020 July 13];0(0):1-19. Available from: https: //doi.org/10.1177/2399808317702148.

[26] Alex AP, Saraswathy MV, Isaac KP. Latent variable enriched mode choice model for work activity in multi modal condition prevalent in India. Int J Traffic Transp Eng [Internet]. 2016 [cited 2020 July 13];6(4):378-89. Available from: http://dx.doi.org/10.7708/ijtte. 2016.6(4).02.

[27] Ababio-Donkor A, Saleh W, Fonzone A. Understanding transport mode choice for commuting: the role of affect. Transp Plan Technol. 2020 Mar;43(4):385-403.

[28] He SY, Thøgersen J. The impact of attitudes and perceptions on travel mode choice and car ownership in a Chinese megacity: The case of Guangzhou. Res Transp Econ. 2017 Jun;62:57-67.

[29] Tiikkaja H, Liimatainen H, Pöllänen M. Satisfaction with general functionality and safety of travel in relation to residential environment and satisfaction with transport modes. Eur Transp Res Rev [Internet]. 2020 May [cited 2020 July 13];12(32):1-14. Available from: https://doi.org/10.1186/s12544-020-00423-9.

[30] Chen J, Li S. Mode choice model for public transport with categorized latent variables. Math Probl Eng [Internet]. 2017 Aug [cited 2020 July 13];2017:1-11. Available from: https://doi.org/10.1155/ $2017 / 7861945$.

[31] Tran MT, Zhang J, Chikaraishi M, Fujiwara A. A joint analysis of residential location, work location and commuting mode choices in Hanoi, Vietnam. J Transp Geogr. 2016 Jun;54:181-93.

[32] Ramezani S, Pizzo B, Deakin E. An integrated assessment of factors affecting modal choice: towards a better understanding of the causal effects of built environment. Transportation (Amst). 2018 Sep;45:1351-87.

[33] Bwire H, Zengo E. Comparison of efficiency between public and private transport modes using excess commuting: An experience in Dar es Salaam. J Transp Geogr [Internet]. 2020 Jan [cited 2020 July 15];82:1-14. Available from: https://doi.org/10.1016/j. jtrangeo.2019.102616.

[34] Habib KMN. Modeling commuting mode choice jointly with work start time and work duration. Transp Res Part A Policy Pract. 2012 Jan;46(1):33-47.

[35] Ermans T, Brandeleer C, Hubert M, Lebrun K, Sieux F. Travel between home and work: current situation and perspectives for action for companies. Brussels Stud [Internet]. 2018 July [cited 2020 July 15];(125):1-32. Available from: https://doi.org/ 10.4000 /brussels.1696.
[36] Ton D, Bekhor S, Cats O, Duives DC, Hoogendoorn-Lanser S, Hoogendoorn SP. The experienced mode choice set and its determinants: Commuting trips in the Netherlands. Transp Res Part A Policy Pract [Internet]. 2020 Feb [cited 2020 July 15];132:744-58. Available from: https://doi.org/10.1016/j.tra.2019.12.027.

[37] Oludeyi OS. A review of literature on work environment and work commitment: Implication for future research in citadels of learning. Hum Resour Manage [Internet]. 2015 Oct [cited 2020 July 16];18(2):32-46. Available from: https://www.jhrm.eu/wpcontent/uploads/2015/03/JournalOfHumanResourceMng2015vo l18issue2-pages-32-46.pdf.

[38] Raziq A, Maulabakhsh R. Impact of working environment on job satisfaction. Procedia Economics and Finance [Internet]. 2015 [cited 2020 July 16];23:717-25. Available from: http://dx.doi.org/ 10.1016/S2212-5671(15)00524-9.

[39] Rehkopf DH, Modrek S, Cantley LF, Cullen MR. Social, psychological, and physical aspects of the work environment could contribute to hypertension prevalence. Health Aff [Internet]. 2017 Feb [cited 2020 July 16];36(2):258-65. Available from: https: //doi.org/10.1377/hlthaff.2016.1186.

[40] Massoudi AH, Hamdi SSA. The consequence of work environment on employees productivity. IOSR J Bus Manag [Internet]. 2017 Jan [cited 2020 July 16];19(1):35-42. Available from: https://doi. org/10.9790/487X-1901033542.

[41] Al-Omari $\mathrm{K}$, Okasheh $\mathrm{H}$. The influence of work environment on job performance: A case study of engineering company in Jordan. Int J Appl Eng Res [Internet]. 2017 [cited 2020 July 16];12(24):15544-50. Available from: https://www.ripublication. com/ijaer17/ijaerv12n24_223.pdf.

[42] Soundarapandiyan K, Kumar TP, Priyadarshini MK. Effects of workplace fun on employee behaviors: An emprical study. Int J Mech Prod Eng Res Dev [Internet]. 2018 Dec [cited 2020 July 16];8(3):1040-50. Available from: https://www.researchgate. net/publication/331928113.

[43] Hair JF, Black WC, Babin BJ, Anderson RE. Multivariat data analysis. 7/e. Pearson Prentice Hall; 2010: 609 p.

[44] Kock N. Using WarpPLS in e-collaboration studies: An overview of five main analysis steps. Int J e-Collaboration [Internet]. 2010 Oct [cited 2020 July 18];6(4):1-11. Available from: https://www. researchgate.net/publication/220474903.

[45] Monecke A, Leisch F. semPLS: Structural equation modeling using partial least squares. J Stat Softw [Internet]. 2012 May [cited 2020 July 18];48(3):1-32. Available from: https://www. researchgate.net/publication/267204270.

[46] Hair JF, Risher JJ, Sarstedt M, Ringle CM. When to use and how to report the results of PLS-SEM. Eur Bus Rev [Internet]. 2019 Jan [cited 2020 July 18];31(1):2-24. Available from: https://doi.org/ 10.1108/EBR-11-2018-0203.

[47] Zhang C, Liu Y, Lu W, Xiao G. Evaluating passenger satisfaction index based on PLS-SEM model: Evidence from Chinese public transport service. Transp Res Part A Policy Pract. 2019 Feb;120:149-64.

[48] Shah SAR, Ahmad N, Shen Y, Pirdavani A, Basheer MA, Brijs T. Road safety risk assessment: An analysis of transport policy and management for low-, middle-, and high-income Asian countries. Sustain [Internet]. 2018 Feb [cited 2020 July 18];10(389):1-30. Available from: https://doi.org/10.3390/su10020389.

[49] Lee JY, Chung JH, Son B. Analysis of traffic accident size for Korean highway using structural equation models. Accid Anal Prev. 2008 Nov;40(6):1955-63. 
[50] Kang AS, Jayaraman K, Soh KL, Wong WP. Social predictors and implementation intention of drivers to use public bus transport. Manag Environ Qual An Int J. 2019 Mar;30(2):307-28.

[51] Scott RA, George BT, Prybutok VR. A public transportation decision-making model within a metropolitan area. Decis Sci. 2016 Dec;47(6):1048-72.

[52] Askari S, Peiravian F, Tilahun N, Baseri YM. Determinants of users' perceived taxi service quality in the context of a developing country. Transp Lett. 2020 Jan;00(00):1-13.

[53] Dreamstime.com. [Internet]. [cited 2020 July 20]. Available from: https://thumbs.dreamstime.com/z/jakarta-administrative-ma p-special-capital-region-flag-71843389.jpg.

[54] Division of Integration Processing and Statistics Dissemination. DKI Jakarta province in figures. Jakarta; 2020. Indonesia.

[55] Ppid.transjakarta.co.id [Internet]. The development of the number of Transjakarta buses 2004-2019. 2020 [cited 2020 July 20]. Available from: https://ppid.transjakarta.co.id/pusat-data/ statistika.Indonesia.

[56] MRT Jakarta PT. Together we create more value [Internet]. Annual Report. 2019. Available from: https://jakartamrt.co.id/sites/ default/files/2020-09/Annual-Report-MRT-Jakarta-2019.pdf.

[57] Silalahi SLB, Handayani PW, Munajat Q. Service quality analysis for online transportation services: case study of Go-jek. Procedia Computer Science [Internet]. 2017 [cited 2020 July 20];124:48795. Available from: https://doi.org/10.1016/j.procs.2017.12.181

[58] Munandar J, Munthe R. How technology affects behavioral intention (case study of online transportation in Indonesia and Thailand). South East Asian J Manag [Internet]. 2019 Oct [cited 2020 July 20];13(2):222-36. Available from: http://journal.ui.ac. id/index.php/tseajm/article/view/11343/67546540.

[59] BPS DKI Jakarta Province. DKI Jakarta transportation statistics 2018 [Internet]. 2018. [cited 2020 July 20]. Available from: https://jakarta.bps.go.id/publication/2018/10/03/cb1285d8d be8be8754a5830d/statistik-transportasi-dki-jakarta-2018.ht ml.Indonesia.

[60] Tomtom.com [Internet]. Jakarta traffic. 2020 [cited 2020 July 20]. Available from: https://www.tomtom.com/en_gb/traffic-index/ jakarta-traffic/.

[61] Bptj.dephub.go.id [Internet]. Jabodetabek transportation master plan. 2019 [cited 2020 July 20]. Available from: http://bptj. dephub.go.id/rencana-induk-transportasi-jabodetabek-ritj.Ind onesia.

[62] Hair JF, Ringle CM, Sarstedt M. PLS-SEM: Indeed a silver bullet. J Mark Theory Pract. 2011 Apr;19(2):139-52.

[63] Sarstedt M, Ringle CM, Hair JF. Partial least squares structural equation modeling. In: Homburg, C; Klarmann, M; Vomberg A, editors. Handbook of market research [Internet]. Springer; 2017 [cited 2020 July 22]. p. 1-40. Available from: https://www. researchgate.net/publication/319669432.

[64] Sarstedt M, Ringle CM, Smith D, Reams R, Hair JF. Partial least squares structural equation modeling (PLS-SEM): A useful tool for family business researchers. J Fam Bus Strateg. 2014 Mar;5(1):105-15.
[65] Kock N. WarpPLS user manual: Version 6.0. [Internet]. Laredo, Texas USA: ScriptWarp System; 2019 [cited 2020 July 22]. Available from: http://cits.tamiu.edu/WarpPLS/UserManual_v_6_0. pdf.

[66] Washington SP, Karlaftis MG, Mannering FL. Statistical and econometric methods for transportation data analysis. 2nd ed. Boca Raton: CRC Press Taylor \& Francis Group; 2011.

[67] Kock N. Factor-based structural equation modeling with WarpPLS. Australas Mark J [Internet]. 2019 Jan [cited 2020 July 22]. Available from: https://doi.org/10.1016/j.ausmj.2018.12.002.

[68] Kock N. Advanced mediating effects tests, multi-group analyses, and measurement model assessments in PLS-based SEM. Int J e-Collaboration [Internet]. 2014 Jan [cited 2020 July 22];10(1):113. Available from: https://www.researchgate.net/publication/ 261960218.

[69] Fornel C, Larcker DF. Evaluating structural equation models with unobservable variables and measurement error. J Mark Res. 1981 Feb;18(1):39-50.

[70] Hair JF, Sarstedt M, Pieper TM, Ringle CM. The use of partial least squares structural equation modeling in strategic management research: A review of past practices and recommendations for future applications. Long Range Plann. 2012 Oct;45(5):320-40.

[71] Henseler J, Ringle CM, Sarstedt M. A new criterion for assessing discriminant validity in variance-based structural equation modeling. J Acad Mark Sci [Internet]. 2015 Jan [cited 2020 July 25];43:115-35. Available from: https://doi.org/10.1007/s11747014-0403-8.

[72] Kock N. Common method bias in PLS-SEM: A full collinearity assessment approach. Int J e-Collaboration [Internet]. 2015 Oct [cited 2020 July 27];11(4):1-10. Available from: https://www. researchgate.net/publication/285590317.

[73] Næss P, Tønnesen A, Wolday F. How and why does intrametropolitan workplace location affect car commuting? Sustain [Internet]. 2019 Feb [cited 2020 July 27];11(4):1-24. Available from: https://doi.org/10.3390/su11041196.

[74] Cheng L, Chen X, Yang S, Wu J, Yang M. Structural equation models to analyze activity participation, trip generation, and mode choice of low-income commuters. Transp Lett. 2017 Aug;11(6):341-9.

[75] Chocholac J, Sommerauerova D, Hyrslova J, Kucera T, Hruska $\mathrm{R}$, Machalik S. Service quality of the urban public transport companies and sustainable city logistics. Open Eng. [Internet]. 2020 Jan [cited 2020 July 27];10(1):86-97. Available from: https: //doi.org/10.1515/eng-2020-0010.

[76] Chu MC, Nguyen LX, Ton TT, Huynh N. Assessment of motorcycle ownership, use, and potential changes due to transportation policies in Ho Chi Minh City, Vietnam. J Transp Eng Part A Syst. 2019 Dec;145(12):1-11.

[77] Wallsten S. The competitive effects of the sharing economy: How is uber changing taxis? [Internet]. 2015 [cited 2020 July 27]. Available from: www.researchgate.net/publication/279514652. 